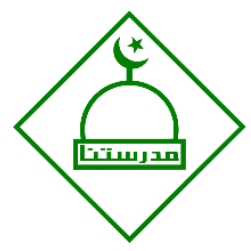

\title{
EFEKTIVITAS MODEL PEMBELAJARAN BERBASIS MULTILITERASI UNTUK MENINGKATKAN KETERAMPILAN MENULIS KREATIF SISWA SEKOLAH DASAR
}

\author{
Ari Metalin Ika Puspita \\ Program Studi Pendidikan Guru Sekolah Dasar STKIP PGRI, Trenggalek, Indonesia \\ arimetalinikapuspita2@gmail.com
}

\begin{abstract}
Research Objectives to determine the effectiveness of the use of literacy-based learning models to improve students' creative writing skills. The research method used is a type of quantative research with a quasi-experimental model. Sampling is done by saturated sample technique, where all members of the population are selected as sample members. Data collection techniques in this study used interviews, observation, and tests. Data analysis using a comparison test. Based on the results of the comparative test show that there are differences in creative writing skills between students who use a literacy-based learning model and students who do not use a literacy-based learning model.
\end{abstract}

Keywords: Literacy, Creative Writing, Learning Models.

\begin{abstract}
ABSTRAK
Tujuan Penelitian untuk mengetahui efektivitas penggunaaan model pembelajaran berbasis literasi untiuk meningkatkan keterampilan menulis kreatif siswa. Metode penelitian yang digunakan adalah jenis penelitian kuantatif dengan model quasi eksperimen. Pengambilan sampel dilakukan dengan teknik sampel jenuh, dimana semua anggota populasi dipilih sebagai anggota sampel. Teknik pengumpalan data pada penelitian ini menggunakan wawancara, observasi, dan tes. Analisis data menggunakan uji komparasi. Berdasarkan hasil uji komparasi menunjukkan bahwa ada perbedaan keterampilan menulis kreatif antara siswa yang menggunakan model pembelajaran berbasis literasi dan siswa yang tidak menggunkaan model pembelajaran berbasis literasi.
\end{abstract}

Kata kunci: Literasi, Menulis Kreatif, Model Pembelajaran.

\section{PENDAHULUAN}

Model pembelajaran yang digunakan oleh guru merupakan salah satu faktor penentu keberhasilan dari suatu proses pembelajaran. Model pembelajaran yang dikemas secara sistematis akan menjadikan suatu proses pembelajaran menjadi efektif dan efisien. Pemilihan dan penggunaan model pembelajaran perlu ditinjau aspek kekuatan dan kelemahannya, agar tidak menimbulkan permasalahan baru yang menurunkan hasil belajar. Model pembelajaran merupakan suatu pola yang dirancang secara terorganisisr yang menggambarkan prosedur pembelajaran yang dijadikan pedoman dalam menyusun rancangan dan aktivitas pembelajaran. Salah satu model pembelajaran yang saat ini banyak dikembangkan di dunia pendidikan yaitu multiliterasi yang merupakan suatu paradigma baru dalam pembelajaran literasi. 
Pembelajaran literasi berimplikasi lahirnya konsep multiliterasi. Munculnya konsep multiliterasi karena manusia tidak hanya membaca dan menulis, akan tetapi aktivitas membaca dan menulis mampu melibatkan tujuan sosial, kultural, dan politik yang merupakan tuntutan pada era globalisasi. Masyarakat yang semakin bergantung pada teknologi untuk akses informasi dan komunikasi bersama dengan globalisasi informasi menuntut warganya untuk secara efektif menggunakan keterampilan yang sangat diperluas untuk mencakup kompetensi budaya dan media baru serta pengakuan atas berbagai konteks di mana mereka diterapkan. (Coiro, Knobel, Lankshear, \& Leu: 2014). Pada abad ke dua puluh satu, inovasi teknologi global telah memberi para pembelajar dengan banyak cara baru untuk bertindak dan berkomunikasi. Banyak ahli teori kontemporer berpendapat bahwa perkembangan tersebut menuntut transformasi dalam pengajaran dan pembelajaran literasi (Kalantzis \& Cope: 2012, Luke: 2013). Model pembelajaran multiliterasi mendorong siswa untuk aktif dan menemukan pengalaman baru dalam proses pembelajaran. Multiliterasi menemukan cara-cara untuk mendorong pembelajaran yang efektif di ruang kelas, multiliterasi menyediakan satu sarana untuk memberikan pengalaman baru yang lebih erat selaras dengan praktik sosial yang berbeda, minat, dan pengalaman yang dibawa siswa ke kelas dan mendorong partisipasi yang berkelanjutan dalam pembelajaran keaksaraan kelas. (Lenters: 2016).

Pada model Multiliterasi ini siswa perlu mengembangkan kapasitas untuk berbicara, bernegosiasi, dan mampu terlibat secara kritis dengan kondisi kerja mereka hidup (New London Group: 1996).Sehingga praktik literasi tidak hanya terbatas pada membaca dan menulis. Praktik literasi sekolah harus menghargai, mengenali, dan mendorong keaksaraan anak-anak CLD dan literasi yang terlibat menggunakan gambar dan mode lain sebagai mediator di seluruh konteks kehidupan mereka yang luas di luar pendekatan yang hanya berbasis keterampilan (Kim: 2016).Peran guru dalam pembelajaran multiliterasi memegang peran yang sangat fundamental, dimana guru perlu mengembangkan alat penilaian saat proses maupun hasil pembelajaran. penilaian multiliterasi meminta serangkaian pertanyaan yang berbeda. Setelah seorang guru secara rutin mengajukan pertanyaan yang membangun pedagogi multiliterasi, maka cara baru untuk penilaian envisioning akan muncul (Jacob: 2013).

Pada model pembelajaran multiliterasi tidak hanya menekankan aspek membaca saja, namun menulis juga penting dalam proses pembelajaran. Menurut Cahyani (2012) menulis adalah kemampuan seseorang untuk menggunakan lambang-lambang bahasa untuk menyampaikan sesuatu baik berupa ide atau gagasan kepada orang lain atau pembaca yang dilakukan dengan menggunakan bahasa tulisan. Kemampuan menulis tidak didapatkan secara spontan, namun melalui proses pembelajaran yang intensif. Dengan memiliki kemampuan menulis yang baik diharapkan gagasan atau ide yang sudah ditulis oleh siswa dapat diterima dan dibaca dengan baik oleh orang lain. Penulisan kreatif bisa diartikan sebagai kemampuan untuk mengendalikan pikiran-pikiran kreatif yang bergumul dalam pikiran seseorang dan untuk menyusunnya ke dalam sebuah kalimat dengan struktur yang baik; konsep dari menulis kreatif lebih 
berbobot daripada menyimpan imaginasi karena tidak semua imajinasi adalah pikiran yang kreatif. Kreativitas lahir di dalam pikiran yang mapan dan matang. Seorang penulis sama baiknya dengan pemikirannya sendiri. Namun hasil menulis kreatif akan bagus jika melakukan kegiatan yang saling merespon, menyunting, mengecek, dan mempresentasikan hasil tulisannya, sehingga Model pembelajaran berbasis multiliterasi sangat dibutuhkan untuk menghasilkan kualitas tulisan yang indah.

Selanjutnya Graves (dalam Akhadiah dkk: 1998) berkaitan dengan manfaat menulis mengemukakan bahwa: (1) menulis mengasah kecerdasan, (2) menulis mengem-bangkan daya inisiatif dan kreativitas, (3) menulis menumbuhkan keberanian, dan (4) menulis mendorong kemauan dan kemampuan mengumpulkan informasi. Pada dasarnya proses menulis berlangsung secara bertahap, setiap orang akan melewati tahapan tersebut, yaitu pramenulis, pemburaman/ pengendrafan, dan perevisian untuk memperbaiki tulisan yang sudah dihasilkan. Pada dasarnya ada lima tahap proses kreatif menulis, yaitu: (1) persiapan, pada tahap ini penulis menyadari apa yang akan ditulis, (2) inkubasi, pada tahap ini gagasan yang telah muncul tadi direnungkan kembali oleh penulis, (3) inspirasi, pada tahap ini penulis menyadari apa yang akan ditulis, (4) penulisan, pada tahap ini penulis mengungkapkan apa yang ingin ditulis, dan (5) revisi.

\section{METODE PENELITIAN}

Jenis penelitian yang digunakan dalam penelitian ini merupakan penelitian kuantitatif. Desain penelitian yang digunakan dalam penelitian ini yaitu menggunakan Quasi Experimental Design. Populasi dalam penelitian ini adalah seluruh siswa/siswi kelas VI SDN 1 Surodakan Kabupaten Trenggalek. Populasi penelitian ini berjumlah 35 siswa yang terdiri dari satu kelas yaitu kelas IV. Pengambilan sampel dilakukan dengan teknik sampel jenuh, dimana semua anggota populasi dipilih sebagai anggota sampel. Sampel yang diambil pada penelitian ini sebanyak 35 siswa. Desain penelitian ini dipilih karna sesuai dengan tujuan yang ingin dicapai, yaitu untuk mengetahui seberapa besar pengaruh antara variabel X (Model pembelajaran literasi) dengan variabel Y (keterampilan menulis kreatif). Gambar Rancangan penelitian ini adalah sebagai berikut:

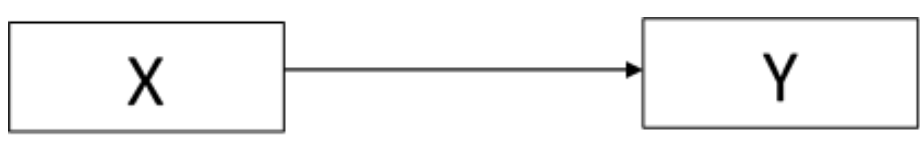

Gambar 1 Rancangan Penelitian

Teknik pengumpalan data pada penelitian ini menggunakan wawancara, observasi, dan tes. Wawancara digunakan untuk mengetahui permasalahan yang dihadapi siswa, Observasi bertujuan untuk mengetahui kondisi siswa sebelum dan pada saat penelitian, sedangkan tes digunakan untuk mengetahui 
hasil penelitian yang dilakukan. Analisis data menggunakan uji komparasi. Uji komparasi ini bertujuan untuk mengetahui perbedaan keterampilan menulis kreatif antara kelas eksperimen dan kelas control. Selanjutnya uji komparasi ini bertujuan untuk mengetahui peningkatan keterampilan menulis kreatif siswa. Uji komparasi dianalisis dengan menggunakan teknik independent sample t-test. Analisis data pada penelitian ini dilakukan dengan Software SPSS 22.

\section{HASIL DAN PEMBAHASAN}

Pada penelitian ini angket diberikan kepada siswa untuk memperoleh data baik yang berasal dari varibel penelitian yaitu variable x (model pembelajaran berbasis literasi) dan variable y (keterampilan menulis kreatif). Pada penerapan model pembelajaran berbasis literasi, peneliti mengobservasi keterampilan menulis kreatif siswa. Penilian terhadap keteramapilan menulis kreatif pada siswa bertujuan untuk mengetahui peneningkatan keterampilan menulis kreatif siswa. Penilaian terhadap hasil keterampilan menulis kreatif siswa ditunjukkan pada Tabel 1 berikut.

\begin{tabular}{|c|c|c|c|}
\hline \multicolumn{4}{|c|}{ Tabel 1 Nilai Hasil Keterampilan Menulis Kretaif } \\
\hline No. & Rentang Nilai & Frekuensi & Persentase $(\%)$ \\
\hline 1 & $91-100$ & 12 & 34,28 \\
\hline 2 & $81-90$ & 11 & 31,4 \\
\hline 3 & $71-80$ & 8 & 22,85 \\
\hline 4 & $61-70$ & 4 & 11,42 \\
\hline 5 & $00-51$ & 0 & 0 \\
\hline Jumlah & & 35 & 100 \\
\hline
\end{tabular}

Berdasarkan Tabel 1 terlihat bahwa keterampilan menulis kreatif siswa pada rentang nilai 91-100 menunjukkan presentase 34,28\%. Siswa yang memperoleh nilai 81-90 sebesar 31,4\%. Sedangkan 8 siswa mendapatkan nilai 71-80 atau sebesar 22,85 \% dari jumlah keseluruhan siswa. Siswa yang memperoleh 61-70\% sebanyak 4 siswa atau 11,42\%. Berdasarkan hasil tersebut menunjukkan bahwa penerapan model pembelajaran berbasis literasi efektif dalam meningkatkan keterampilan menulis kreatif siswa.

Hasil analisis data dalam penelitian ini berdasarkan keterampilan menulis kreatif siswa dalam proses pembelajaran ketikan menggunkan model pembelajaran berbasis literasi. Untuk mengetahui keefektifan model pembelajaran berbasis literasi digunakan uji komparasi dengan menggunakan formula Mann-Whitney U Test karena tidak terpenuhinya uji normalitas. Hasil uji asumsi normalitas ditunjukkan pada Tabel 2 berikut.

Tabel 2 Uji Normalitas Model Pembelajaran Berbasis Literasi

\section{Tests of Normality}

\begin{tabular}{ll|l|l|l|l|l|l|}
\multicolumn{4}{l}{} & \multicolumn{3}{l}{ Kolmogorov-Smirnovia } & \multicolumn{2}{l}{ Shapiro-Wilk } \\
NILAI & KELOMPOK & Statistic & Df & Sig. & Statistic & df & Sig. \\
\cline { 2 - 9 } & KELOMPOK_KONTROL .153 & 52 & .001 & .914 & 52 & .002 \\
\hline
\end{tabular}




\begin{tabular}{ll|l|l|l|l|l}
\hline $\begin{array}{l}\text { KELOMPOK_EKSPERIM .120 } \\
\text { EN }\end{array}$ & 52 & .028 & .938 & 52 & .011 \\
\hline
\end{tabular}

a. Lilliefors Significance Correction

Berdasarkan Tabel 2 dari hasil uji normalitas dengan menggunakan formula kolmogorov-smirnov diketahui bahwa keterampilan menulis kreatif pada kelompok kontrol tidak berdistribusi normal karena nilai signifikansinya dibawah $0.02(0.001<0.05)$. Data hasil menulis kreatif pada kelompok eksperimen juga tidak berdistribusi normal, hal ini ditunjukkan dari nilai signifikansinya yang berada di bawah 0.05 $(0.028<0.05)$. Jadi kedua data tersebut tidak berdistribusi normal.

Sedangkan pada Uji Homogenitas keterampilan menulis kreatif siswa dengan model pembelajaran berbasis literasi ditunjukkan pada Tabel 3 sebagai berikut.

Tabel 3 Uji Homogenitas Keterampilan menulis kreatif siswa

Test of Homogeneity of Variances

\begin{tabular}{|c|c|c|c|c|c|}
\hline & & Levene Statistic & df1 & df2 & Sig. \\
\hline \multirow[t]{4}{*}{ NILAI } & Based on Mean & 3.253 & 1 & 102 & .063 \\
\hline & Based on Median & 2.090 & 1 & 102 & .151 \\
\hline & $\begin{array}{l}\text { Based on Median and with } \\
\text { adjusted df }\end{array}$ & 2.090 & 1 & 93.736 & .152 \\
\hline & Based on trimmed mean & 2.972 & 1 & 102 & .088 \\
\hline
\end{tabular}

Berdasarkan Tabel 3 diperoleh nilai signifikansi sebesar 0.063 (> 0.05) sehingga dapat dikatakan bahwa data hasil keterampilan menulis kreatif pada kelompok kontrol dan kelompok eksperimen memiliki varian yang sama atau homogen.

Berdasarkan hasil uji asumsi normalitas diketahui bahwa semua data tidak berdistribusi normal, sedangkan dari uji homogenitas diketahui bahwa data pada kedua kelompok homogen. Karena salah satu uji asumsi tidak terpenuhi maka uji komparasi parametrik dengan Independent Sample T-Test tidak dapat digunakan, sehingga sebagai alternatif uji analisis dilakukan dengan menggunakan formula Mann-Whitney U Test. .

\section{Tabel 4 Uji Komparasi}

\begin{tabular}{ll} 
Test Statistics $^{\mathbf{a}}$ & NILAI \\
\hline Mann-Whitney U & 950.000 \\
\hline Wilcoxon W & 2328.000 \\
\hline Z & -2.618 \\
\hline Asymp. Sig. (2-tailed) & .008 \\
\hline a. Grouping Variable: KELOMPOK &
\end{tabular}

Tabel 4 menunjukkan bahwa nilai signifikansi yang diperoleh sebesar $0.008(0.009<0.05)$. Hasil tersebut menunjukkan bahwa ada perbedaan keterampilan menulis kreatif antara siswa yang menggunakan model pembelajaran berbasis literasi dan siswa yang tidak menggunkaan model pembelajaran berbasis literasi,

Abidin (2015) menyatakan bahwa Multiliterasi adalah keterampilan menggunakan beragam cara untuk menyatakan dan memahami ide-ide dan informasi dengan menggunakan bentuk-bentuk teks konvensional maupun teks inovatif, simbol, dan multimedia.Sedangkan New London Group (2000) 
Multiliterasi merupakan bagian integral dari dunia yang beragam, multimodal, dan berbasis informasi. Multiliterasi berorientasi keaksaraan dengan desain, dengan fokus utama pada produksi teks yang ditransformasikan, dapat mempersempit kemungkinan untuk membuka masa depan siswa yang ingin dipromosikan (Leander \& Boldt: 2013, Skerrett: 2015).

Ada tiga contoh kelompok kegiatan penelitian tinggi di Amerika Latin yang melibatkan ide-ide multiliterasi: (1) pendidikan keaksaraan dan keaksaraan kritis; (2) adat, bilingual, dan pendidikan antarbudaya; dan (3) teknologi dan melek digital (Carrillo, Rogers: 2017). The New London Group (1996) berpendapat bahwa "pedagogi multiliteracies" diperlukan jika siswa untuk memenuhi kompleks, tuntutan bervariasi dari berbagai bentuk komunikasi yang dibawa oleh pengenalan teknologi baru.

Penerapan multiliterasi tidak hanya terbatas pada lingkup sekolah serta membaca dan menulis, namun sejalan perkembangan zaman transformasi dari literasi menjadi multiliterasi dapat dijadikan sebagai acuan untuk mengembangkan kemampuan yang lain. Multiliterasi melekat pada aspek-aspek membaca sehingga mampu menciptakan sumber daya manusi melek teknologi. Menurut Puspita (2019) mengatakan bahwa Budaya literasi yang ada pada diri siswa akan mempengaruhi tingkat keberhasilan baik di sekolah maupun masyarakat salah satunya yaitu tentang pemerolehan karakter pada siswa. Salah satu komponen dari multiliterasi yaitu membaca dan menulis.

Menulis adalah kegiatan produktif dan ekspresif yang merupakan salah satu keterampilan bahasa. Menulis merupakan hasil olah pikiran dan juga perasaan yang dituangkan dalam karya tulisan tangan. Menulis juga sebagai kegiatan produktif yang menghasilkan karya dalam bentuk tulisan. Menulis dapat dikatakan sebagai hasil nyata dari gagasan kita yang dituangkan pada goresan tangan untuk menyampaikan pesan kepada pembaca. Menurut Semi (2007) dalam bukunya mengungkapkan pengertian menulis adalah suatu proses kreatif memindahkan gagasan ke dalam lambang-lambang tulisan. Selanjutnya Nurgiantoro (1988) menyatakan bahwa menulis adalah aktivitas aktif produktif, yaitu aktivitas menghasilkan bahasa. Nurjamal dalam Sumirat, Darwis (2011) mengemukakan bahwa menulis sebagai sebuah keterampilan berbahasa adalah kemampuan seseorang dalam mengemukakan gagasan, perasaan, dan pemikiran pemikirannya kepada orang atau pihak lain dengan menggunakan media tulisan.

\section{KESIMPULAN DAN SARAN}

Pada model pembelajaran berbasis literasi tidak hanya menekankan pada aspek membaca, namun keterampilan menulis juga memegang peranan yang sangat penting. Pada keterampilan menulis tidak dapat diperoleh secara cepat dan instan, namun dibutuhkan pembelajaran dan proses yang intensif. Keterampilan menulis kreatif yang dimiliki oleh siswa diharapkan isi atau pesan yang ditulis dapat diterima dan dibaca dengan baik oleh siswa. 
Keterampilan menulis kreatif siswa dapat muncul dengan penerapan model pembelajaran yang tepat. Model pembelajaran dipilih dengan menggunakan analisis karakteristik dan kebutuhan siswa. Sehingga tujuan dari pembelajaran yang sudah disusun dapat tercapai secara optimal.

\section{DAFTAR PUSTAKA}

Abidin, Y. (2014). Desain Sistem Pembelajaran dalam Konteks Kurikulum 2013. Bandung: PT Refika Aditama.

Anderson B. (2000). Doppler assessment of left ventricular diastolic function." Echocardiography: the normal examination and echocardiographic measurements. First Edition. Queensland: MGA graphics.

Bayraktara, A. (2012) Teaching writing through teacher-student writing conferences. Procedia - Social and Behavioral Sciences 51 (2012) $709-713$.

Bell-Gredler, Margaret E. (1986). Learning and Instruction: Theory into Practice. New York: Mac Millan Publishing Company.

Borg, M. \& Gall, D. (1983). Educational Research an Intruduction (fourth edition). Newyork \& London: Longman.

Calkins, L.M. (1986). The Art of Teaching Writing. New York:Hampsiher Heinemann

Darwis, dkk. 2011. Terampil Berbabasa. Bandung: Alfabeta

Fang, Z. (2005). Scientific Literacy: A Systemic Functional Linguistics Perspective. Sci Ed. 89, 335- 347.

Komariyah, N. (2016). Upaya Meningkatkan Ketrampilan Menulis Puisi Dengan Metode "Conference Writing "Pada Siswa Kelas VIIB Semester Genap Smp Negeri 2 Asembagus Kabupaten Situbondo Tahun Pelajaran 2012/2013 Jurnal Pancaran Pendidikan Vol 5 No 2 (2016)

Kalantzis, M., Cope, B., \& Harvey, A. 2003. Assessing multiliteracies and the new basics. Assessment in Education: Principles, Policy \& Practice, 10, 15 -26. doi:10.1080/09695940301692

Leander, K. M., \& Boldt, G. 2013. Rereading "A pedagogy of multiliteracies: Texts, identities, and futures. Journal of Literacy Research, 45, 22 -46. doi:10.1177/1086296X12468587

New London Group. 1996. A pedagogy of multiliteracies: Designing social futures. Harvard Educational Review, 66, 60 -92. doi:10.17763/ haer.66.1.17370n67v22j160u

Nurgiyantoro, B.1998. Teori Pengkajian Fiksi. Yogyakarta: Gajahmada University Press

Parry, Jo-Ann and Hornsby, D. (1985). Write on: A Conference Writing. Heinmann-Portsmonth, NH

Puspita, A. M. I. (2019). Peran Budaya Literasi Pada Peningkatan Karakter Siswa Sekolah Dasar. Jurnal Pendidikan: Pedagogia (8) No. 1

Skerrett, A. (2015, December). "The soul of the music." Attending to purpose, imagination, and embodied experience in new literacies research. Paper presented at the 65th annual meeting of the Literacy Research Association, Carlsbad, CA.

Semi, M.A. 2007. Dasar-Dasar Keterampilan Menulis. Bandung: Angkasa

Syafie’ie, I. 1988.Retorika Dalam Menulis. Jakarta: P2LPTK Depdikbud 
Sperling, M. (1991). Dialogues of deliberation: Conversation in the teacher-student writing conference. Written Communication, 8, 131-162.

Tarigan, H.G. 1986. Menulis Sebagai Suatu Keterampilan Berbahasa. Bandung: Penerbit Angkasa 